\title{
Transcultural adaptation of the Amyotrophic Lateral Sclerosis Depression Inventory to Brazilian Portuguese
}

\author{
Tatiana Lins Carvalho1, Maria Clara de Oliveira Magalhães², Pedro Lucas de Mendonça Barbosa², \\ Carolina da Cunha Correia ${ }^{1}$
}

1 Hospital Universitário Oswaldo Cruz, Universidade de Pernambuco (UPE), Recife, PE, Brazil.

${ }_{2}^{2}$ Medical Sciences College, UPE, Recife, PE, Brazil.

Received: 6/11/2015 - Accepted: 7/1/2015

DOl: 10.1590/0101-60830000000059

Carvalho TL et al. / Arch Clin Psychiatry. 2015;42(4):111-2

Dear Editor

Depression symptoms in patients with Amyotrophic Lateral Sclerosis (ALS) has been investigated using instruments not specific and may interfere in results ${ }^{1-3}$.

Given the evolution and physical impairment caused by ALS, the ALS Depression Inventory (ADI) was created in 2005 to assess depression symptoms in these individuals. Results have shown a reduction in 12 items also providing accurate measures of depression symptoms in severely paralyzed patient $s^{4,5}$. In light of the instrument's accuracy in detecting depression symptoms at any stage of ALS, and since it has yet to be used in Brazil, it was necessary to translate and transculturally adapt the ADI-12 to Brazilian Portuguese.

There are formal stages for translating and adapting instruments. Attention to linguistics must be given during translation, due to the different semantics between languages. The method proposed by Beaton et al. ${ }^{6}$ was used as a model. The pre-final version was applied to 15 patients diagnosed with ALS in accordance with El Escorial-R

at the Neuromuscular Disease Outpatient Clinic of Oswaldo Cruz University Hospital (HUOC) of University of Pernambuco (UPE). Participants were questioned to determine whether the responses actually corresponded to what the individuals understood and if changes needed to be made to the document. All subjects were aged 18 years and older, of both sexes and gave their informed consent.

The study was conducted between December 2013 and November 2014, after approval was obtained from the Research Ethics Committee of University of Pernambuco/PROPEGE (CAAE: 25749413.2.0000.5207)

Table 1 shows the results of the versions of the ADI- 12 according to the stages of transcultural adaptation. A number of subtle changes were made to conform with Brazilian Portuguese. For example the term "consists of" is translated as "consta de", but we preferred to translate it as "consiste em", more commonly used in our language and therefore easier for the subjects to understand.

Table 1. Original version (English), synthesis of the translation and final version of the ADI-12 in Portuguese

\begin{tabular}{|c|c|c|c|}
\hline Question & Original version (English) & Synthesis of the translation & Final version (Portuguese) \\
\hline Enunciation & $\begin{array}{l}\text { This questionnaire consists of } 12 \text { statements with } \\
4 \text { possible answers: "I fully agree", "I agree", "I } \\
\text { don't agree" and "I do not agree at all". Please } \\
\text { read every statement precisely and think about } \\
\text { to what extent the statement is applicable to you } \\
\text { in the last two weeks including today. Please } \\
\text { mark (tick) the right answer for you. Please cross } \\
\text { only one answer at a time and do not leave any } \\
\text { statements open }\end{array}$ & $\begin{array}{l}\text { Este questionário consiste em } 12 \text { afirmações com } \\
4 \text { respostas possíveis: "Eu concordo plenamente", } \\
\text { "Eu concordo", "Eu não concordo" e "Eu não } \\
\text { concordo de forma alguma". Por favor, leia cada } \\
\text { afirmativa com atenção e pense em até que ponto } \\
\text { a afirmação se aplica a você nas duas últimas } \\
\text { semanas, incluindo hoje. Por favor, marque (faça } \\
\text { um X) a resposta correta para você. Por favor, } \\
\text { marque apenas uma resposta por vez e não deixe } \\
\text { nenhuma afirmativa em aberto }\end{array}$ & $\begin{array}{l}\text { Este questionário consiste em } 12 \text { declarações } \\
\text { com } 4 \text { respostas possíveis: "Eu concordo } \\
\text { totalmente", "Eu concordo", "Eu não concordo" } \\
\text { e "Eu não concordo de forma alguma". Por favor, } \\
\text { leia cada declaração com atenção e pense em } \\
\text { até que ponto a declaração se aplica a você nas } \\
\text { últimas duas semanas, incluindo hoje. Por favor, } \\
\text { marque um X na resposta correta para você. Por } \\
\text { favor, marque apenas uma resposta por vez e não } \\
\text { deixe nenhuma declaração em aberto }\end{array}$ \\
\hline 1 & I am happy and I smile often & Eu estou feliz e sorrio frequentemente & Eu estou feliz e sorrio frequentemente \\
\hline 2 & I can appreciate life despite my circumstances & $\begin{array}{l}\text { Eu consigo apreciar a vida apesar das minhas } \\
\text { circunstâncias }\end{array}$ & $\begin{array}{l}\text { Eu consigo apreciar a vida apesar das minhas } \\
\text { limitações }\end{array}$ \\
\hline 3 & I can get away from it all and I am often relaxed & $\begin{array}{l}\text { Eu consigo me desligar de tudo e me sinto } \\
\text { frenquentemente relaxado(a) }\end{array}$ & $\begin{array}{l}\text { Eu consigo me desligar de tudo e me sinto } \\
\text { frequentemente relaxado(a) }\end{array}$ \\
\hline 4 & I feel alive and vital & Eu me sinto vivo(a) e com muita energia & Eu me sinto vivo(a) e com muita energia \\
\hline 5 & More often than not I am sad & Geralmente, eu me sinto triste & Com muita frequência, eu me sinto triste \\
\hline 6 & I have lost all interest in family and friends & Eu perdi todo o interesse na família e nos amigos & Eu perdi todo o interesse na família e nos amigos \\
\hline 7 & Most often I feel empty & Na maioria das vezes eu me sinto vazio(a) & Frequentemente eu me sinto vazio(a) \\
\hline 8 & $\begin{array}{l}\text { There is nothing that I look forward to or that I } \\
\text { can enjoy }\end{array}$ & $\begin{array}{l}\text { Não existe nada pelo que eu anseie ou que eu } \\
\text { possa apreciar }\end{array}$ & $\begin{array}{l}\text { Não existe nada que eu me interesse ou que eu } \\
\text { possa apreciar }\end{array}$ \\
\hline 9 & $\begin{array}{l}\text { I often feel lost and abandoned and don't know } \\
\text { how to carry on }\end{array}$ & $\begin{array}{l}\text { Eu costumo me sentir perdido(a) e abandonado(a) } \\
\text { e não sei como seguir em frente }\end{array}$ & $\begin{array}{l}\text { Eu geralmente me sinto perdido(a) e } \\
\text { abandonado(a) e não sei como seguir em frente }\end{array}$ \\
\hline 10 & I look forward to every new day & Eu fico ansioso(a) por cada novo dia & Eu fico ansioso(a) por cada novo dia \\
\hline 11 & I often wish I were dead & Eu desejo estar morto(a) com frequência & Eu frequentemente desejo estar morto(a) \\
\hline 12 & I feel like I have lost all of my energy & $\begin{array}{l}\text { Eu me sinto como se tivesse perdido toda minha } \\
\text { energia }\end{array}$ & $\begin{array}{l}\text { Sinto como se tivesse perdido toda a minha } \\
\text { energia }\end{array}$ \\
\hline
\end{tabular}


In the clause "I can appreciate life", the verb "can" means ability and not permission; therefore the clause was translated as "eu consigo apreciar a vida" instead of "eu posso apreciar a vida". The term "get away from it" is best translated as "se desligar"; thus the clause "I can get away from it all" was translated as "eu consigo me desligar de tudo" instead of "eu consigo me livrar de tudo" or "eu consigo lidar com tudo". The remaining questions required less adaptation since their literal translation expressed their real intention and did not compromise the intended meaning.

In this cultural adaptation process the patients encountered no difficulty during the application of any of the questions. Therefore, the ADI- 12 was considered equivalent to the original English version in terms of semantics and expression of concepts, without requiring subsequent adjustments.

Translation of the ADI-12 to Brazilian Portuguese and its adaptation to the socioeconomic and cultural conditions of our people makes this instrument a useful additional parameter to help identify depression symptoms in patients with ALS, thereby improving the care provided to these individuals. A study with a larger sample size is needed to validate the instrument.

\section{Acknowledgements}

We thank all the patients and caregivers who provided their time and contributed to the study.

\section{Disclosure of interests and source of funding}

The authors report no conflict of interest and none source of funding.

\section{References}

1. Ferentinos P, Paparrigopoulos T, Rentzos M, Zouvelou V, Alexakis T, Evdokimidis I. Prevalence of major depression in ALS: comparison of a semi-structured interview and four self-report measures. Amyotroph Lateral Scler. 2011;12(4):297-302.

2. Oh H, Sin MK, Schepp KG, Choi-Kwon S. Depressive symptoms and functional impairment among amyotrophic lateral sclerosis patients in South Korea. Rehabil Nurs. 2012;37(3):136-44.

3. Jelsone-Swain L, Persad C, Votruba KL, Weisenbach SL, Johnson T, Gruis KL, et al. The Relationship between Depressive Symptoms, Disease State, and Cognition in Amyotrophic Lateral Sclerosis. Front Psychol. 2012;3:542.

4. Kübler A, Winter S, Kaiser J, Birbaumer N, Hautzinger M. Das ALS-Depressionsinventar (ADI). Z Klin Psychol Psychother (Gott). 2005;34(1):19-26.

5. Hammer EM, Häcker S, Hautzinger M, Meyer TD, Kübler A. Validity of the ALS-Depression-Inventory (ADI-12) - a new screening instrument for depressive disorders in patients with amyotrophic lateral sclerosis. J Affect Disord. 2008;109(1-2):213-9.

6. Beaton D, Bombardier C, Guillemin F, Ferraz MB. Recommendations for the Cross-Cultural Adaptation of Health Status Measures. New York: American Academy of Orthopaedic Surgeons; 2002. 